\title{
Look before you leap: a curious case of giant pulmonary bulla
}

\author{
Abhilash Koratala, Vikrampal Bhatti
}

Department of Nephrology, University of Florida College of Medicine, Gainesville, Florida, USA

\section{Correspondence to} Dr Abhilash Koratala, akoratsla@ufl.edu

Accepted 3 April 2017

\section{DESCRIPTION}

A 56-year-old white woman with a history of chronic obstructive pulmonary disease, hypertension, deep vein thrombosis and chronic alcohol abuse was brought to the emergency room after having two episodes of seizures at home. She was confused and could not give any history. Vital signs were stable and limited neurological exam was unremarkable except for confusion. CT scan of the head was negative for any acute intracranial abnormality and she was admitted for presumed alcohol withdrawal. Soon after admission, she developed shortness of breath, tachycardia and a low-grade fever. On auscultation, she was found to have no breath sounds on the right and a chest X-ray was obtained which showed a large lucency occupying the majority of the right hemithorax (figure 1). The next question for us was if this was a tension pneumothorax and if the patient needs an urgent tube thoracostomy. However, because

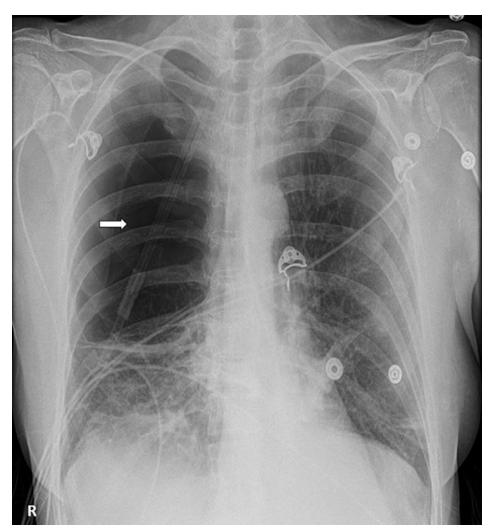

Figure 1 Chest X-ray demonstrating a large lucency (arrow) occupying majority of the right hemithorax.

\section{Learning points}

- Bullous emphysema is typically seen in patients with chronic obstructive pulmonary disease, and when bullae occupy more than $30 \%$ of hemithorax, they are called 'giant bullae.'2

- Giant bullae can mimic pneumothorax and a CT scan is required in such cases to avoid misdiagnosis and unnecessary procedures.

- An important differentiating factor between these two entities on imaging is that the lung collapses towards the ipsilateral hilum unless there are adhesions in case of pneumothorax, while the lung is draped around the bulla with the giant pulmonary bulla. ${ }^{3}$

of the history of bullous chronic obstructive pulmonary disease and deep vein thrombosis, we obtained a CT scan of the chest to exclude giant bulla mimicking pneumothorax and/or pulmonary embolism. CT scan excluded pulmonary embolism and demonstrated a large lucency on the right hemithorax together with bilateral chronic emphysematous changes (figure 2) and basal opacities suggestive of aspiration. There were no signs suggestive of accompanying pneumothorax such as air outlining both sides of the bulla wall parallel to the chest wall (known as the double wall sign'). ${ }^{1}$ The patient's clinical status improved with supplemental oxygen and intravenous antibiotic therapy. She opted against bullectomy and was asymptomatic at discharge.

Contributors AK has prepared the manuscript. VB has reviewed and revised the manuscript and approved for final submission.
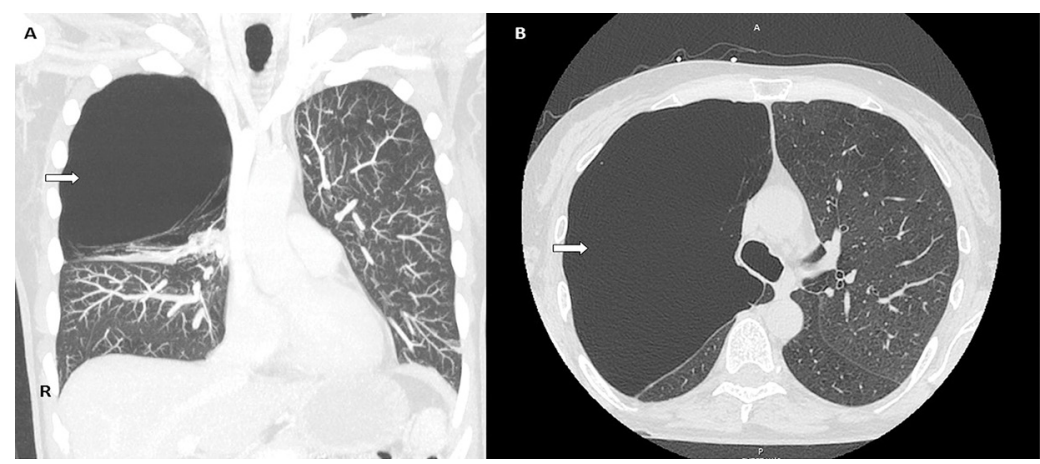

Figure 2 Coronal $(\mathrm{A})$ and transverse (B) views of the CT scan of the chest demonstrating the giant pulmonary bulla (arrows) on the right without pneumothorax; chronic emphysematous changes can be seen in the background. 


\section{Images in...}

\section{Competing interests None declared.}

\section{Patient consent Obtained.}

Provenance and peer review Not commissioned; externally peer reviewed.

(c) BMJ Publishing Group Ltd (unless otherwise stated in the text of the article) 2017. All rights reserved. No commercial use is permitted unless otherwise expressly granted.

\section{REFERENCES}

1 Sarangi PK, Nahak SK, Parida S, et al. A rare case of vanishing lung syndrome with pneumothorax: importance of computed tomography. Int J Sci Rep 2016;2:292-52.

2 Im Y, Faroogi S, Mora A. Vanishing lung syndrome. Proc (Bayl Univ Med Cent) 2016;29:399-401.

3 Vega ME, Civic B. Images in clinical medicine: a tension Bulla mimicking tension pneumothorax. N Engl J Med 2011;365:1915.

Copyright 2017 BMJ Publishing Group. All rights reserved. For permission to reuse any of this content visit http://group.bmj.com/group/rights-licensing/permissions.

BMJ Case Report Fellows may re-use this article for personal use and teaching without any further permission.

Become a Fellow of BMJ Case Reports today and you can:

- Submit as many cases as you like

- Enjoy fast sympathetic peer review and rapid publication of accepted articles

- Access all the published articles

Re-use any of the published material for personal use and teaching without further permission

For information on Institutional Fellowships contact consortiasales@bmjgroup.com

Visit casereports.bmj.com for more articles like this and to become a Fellow 